\title{
Effects of transhumance route on the richness and composition of bird communities in Tsimanampesotse National Park
}

\author{
Lalatiana O. Randriamiharisoa', Daniel Rakotondravony', \\ Marie Jeanne Raherilalao', Amadou Ranirison", Lucienne \\ Wilméll, Joerg U. GanzhornIV
}

Correspondence:

Lalatiana O. Randriamiharisoa

Department of Animal Biology, Faculty of Sciences, University of Antananarivo, BP 906, Antananarivo 101, Madagascar

E-mail: r.5tio@yahoo.fr

\begin{abstract}
In southwestern Madagascar, livestock (cattle) is a major source of income for the human population and is of tremendous cultural importance. In this subarid region, the farming system faces an extreme climate and has to cope with little food and water resources for several months a year. Local farmers overcome these difficulties in the form of transhumance and roaming of cattle in the forest at Tsimanampesotse National Park. The former strategy uses routes directly through the park twice per year. To assess possible effects of the transhumance and associated human activities on birds, we compared the composition and abundance of birds at one control site and two sites along the trail of transhumance in the forest of Tsimanampesotse National Park from January to May 2012. The results showed that the abundance of birds declined near the trail of transhumance. Ten species of birds were hunted during the transhumance to meet the daily needs of the herders. We interpret the lower density of birds along the trail of transhumance as a consequence of hunting, especially for large and terrestrial birds such as Coua spp. Cattle activities (trampling, grazing) do not seem to bird communities.
\end{abstract}

\section{RÉSUMÉ}

Dans le sud-ouest de Madagascar, l'élevage (zébus, chèvres, moutons) est une source majeure de revenus pour la population et représente une importance culturelle. Dans cette région subaride, le système d'élevage est soumis à un climat extrêmement sec et fait face à un manque de nourriture et d'eau pendant plusieurs mois par an. Pour faire face à ces difficultés, les éleveurs pratiquent la transhumance et laissent divaguer le bétail dans la forêt du Parc National de Tsimanampesotse ; cette stratégie a ainsi ouvert une piste qui traverse le parc. Traditionnellement, à savoir avant l'intensification de vol de bétail sur le plateau Mahafaly, les zébus étaient menés de la plaine côtière au plateau dès le début de la saison des pluies lorsque l'eau était disponible. À la fin des pluies, l'eau devenait rare sur le plateau et les zébus retournaient sur la plaine côtière, en traversant ainsi le parc une deuxième fois. Ce parc est classé parmi les zones abritant une richesse biologique unique, il est la seule aire protégée sur le littoral du sud-ouest de Madagascar et sur le plateau calcaire Mahafaly. La particularité de la flore et de la végétation du parc se manifeste par différents types d'adaptation à la sécheresse et à la chaleur. La richesse faunique est caractérisée par des espèces à la fois endémiques et menacées avec une diversité d'oiseaux qui pourrait être affectée par des activités anthropiques dans le parc. Pour évaluer les effets possibles de la transhumance sur l'avifaune, la composition et l'abondance des oiseaux, un site de contrôle a été comparé avec deux sites distribués le long de la piste de transhumance dans la forêt du Parc National de Tsimanampesotse de janvier à mai 2012. Les résultats montrent que I'abondance des oiseaux diminue le long de la piste de transhumance alors que la richesse spécifique n'est pas affectée. Dix espèces d'oiseaux sont chassées pendant la transhumance pour répondre aux besoins quotidiens des éleveurs. La densité plus faible des oiseaux le long de la piste de transhumance est interprétée comme un résultat de la chasse, en particulier les oiseaux les plus grands et les terrestres tels les espèces de Coua. Le piétinement des zébus qui errent à proximité de la piste durant la transhumance pourrait également affecter le sous-bois, I'habitat de certains oiseaux mais la chasse semble rester le facteur anthropique principal affectant les communautés d'oiseaux dans le parc. La transhumance est une stratégie efficace pour le système d'élevage dans les zones subarides mais elle représente un risque par I'ouverture aux ressources naturelles dans le parc.

\section{INTRODUCTION}

Madagascar is one of the world's most important centers of biodiversity (Ganzhorn et al. 2001, Joppa et al. 2013), with exceptionally high species diversity and levels of endemism in all major taxono-

Department of Animal Biology, Faculty of Sciences, University of Antananarivo, BP 906, Antananarivo 101, Madagascar Department of Ecology and Vegetation Conservation, Faculty of Sciences, University of Antananarivo, BP 906, Antananarivo 101, Madagascar Missouri Botanical Garden, Madagascar Research \& Conservation Program, BP 3391, Antananarivo 101, Madagascar Department Animal Ecology and Conservation, University of Hamburg, Martin-Luther-King Platz 3, 20146 Hamburg, Germany 


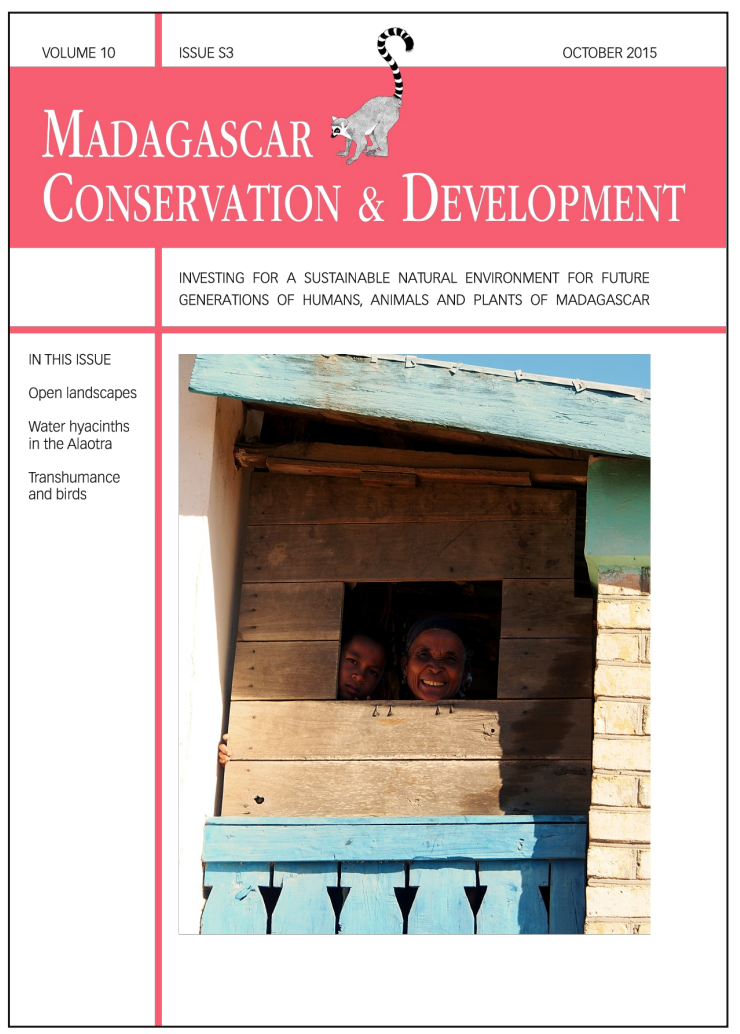

Madagascar Conservation \& Development is the journal of Indian Ocean e-Ink. It is produced under the responsibility of this institution. The views expressed in contributions to MCD are solely those of the authors and not those of the journal editors or the publisher.

All the Issues and articles are freely available at http://www.journalmcd.com

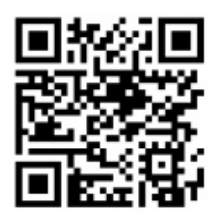

Contact Journal MCD

info@journalmcd.net for general inquiries regarding MCD funding@journalmcd.net to support the journal

Madagascar Conservation \& Development Institute and Museum of Anthropology

University of Zurich

Winterthurerstrasse 190

$\mathrm{CH}-8057$ Zurich

Switzerland

Indian Ocean e-Ink

Promoting African Publishing and Education

www.ioeink.com

Missouri Botanical Garden (MBG)

Madagascar Research and Conservation Program

BP 3391

Antananarivo, 101, Madagascar 
mic groups including birds (Goodman and Benstead 2005, Raherilalao and Goodman 2011). In southwestern Madagascar the 202,525 hectares Tsimanampesotse National Park was created to protect the unique biological richness of the region and plays a key role in the conservation of the regional bird community, comprising at least 112 species (Goodman et al. 2002). Unfortunately, the remaining natural habitats are under pressure from human activities (Blanc-Pamard and Ramiarantsoa 2003, Primack and Ratsirarson 2005, Brinkmann et al. 2014).

In the region, livestock (zebu, Bos taurus, the most common cattle in Madagascar, goats Capra hircus and sheep Ovies aries) is a major source of income for the human population (Feldt 2015). The area is characterized by an extremely dry climate and shortage of food and water for several months (Raherilalao and Wilmé 2008). Breeders have developed a strategy to overcome those difficulties in the form of transhumance and roaming. Transhumance is defined as seasonal migration of livestock from one pasture to another (Nedelea and Comãnescus 2009). The park is crossed by several routes of transhumance and the forest is used for zebu grazing throughout the cool dry season, from April to October (Projet SuLaMa 2011, Ratovonamana et al. 2013). Transhumance is a traditional farming system in this region which had existed before the creation of the park (Project SuLaMa 2011). In 1927, Tsimanampesotse was created as a Strict Nature Reserve (RNI N. 12 Tsimanampetsotsa) of 42,300 hectares, and became the National Park N. 16 of Tsimanampesotse in 2002, that was extended towards the south in 2009, and extended to a total area of 202,525 hectares in April 2015 (MEEMF 2015). In the traditional transhumance zebus and to a lesser extent also sheep are brought from the coastal plain to the Mahafaly Plateau at the beginning of the wet season (October/November) when water is available on the plateau. By the end of the wet season (March/April), water becomes scarce on the plateau and the zebus are taken back to the coastal plain, thus crossing the park twice. While the transhumance itself only takes about two days (one way), the trails are used to transport a variety of goods throughout the year. Thus, the trails are the source of a variety of possible disturbances for fauna and flora. Humans need firewood and probably collect other forest resources as they are encountered along the trail. Further, livestock roaming in the forest can destroy the undergrowth (Ratovonamana et al. 2013) and thus have a negative impact on habitat quality of birds (Soarimalala and Raherilalao 2008). In order to come to a better understanding of the effects of anthropogenic impacts on Madagascar's native fauna, we are assessing the effects of the transhumance trail through the park on the community composition and density of birds. Our working hypothesis was that bird communities would be affected negatively in the proximity of the trail of transhumance.

\section{METHODS}

STUDY SITE. The study was carried out in Tsimanampesotse National Park (E043 $46^{\prime}-43^{\circ} 50^{\prime}, \mathrm{S}^{\circ} 4^{\circ} 03^{\prime}-24^{\circ} 12^{\prime}$ ) between January and May 2012 at an altitude between 38 and $114 \mathrm{~m}$ on the Mahafaly Plateau. The region is characterized by a sub-arid bioclimate (Cornet 1972) with annual rainfall of $350 \mathrm{~mm}$ to $500 \mathrm{~mm}$ (Blanc and Paulian 1996, Dewar and Richard 2007). Inventories were carried out in three different sites in the Tsimanampesotse National Park. Site 1 was the control site, located about $1 \mathrm{~km}$ away from the transhumance route and characterized by intact vegetation where human disturbances are limited. Sites 2 and 3 were lo- cated along the route of transhumance that is used by local people for moving between the plateau and the littoral zone, or for livestock roaming or for transhumance. Site 2 is located at the beginning of the route and Site 3 in the middle (Figure 1). The vegetation types of the different study sites area depend on the type of soil at each site and were classified according to Ratovomanana et al. in 2011 (Table 1).

BIRD SAMPLING. The composition and abundance of birds were recorded with point counts (Bibby et al. 2000, O'Dea et al. 2004). Points were spaced at $100 \mathrm{~m}$ intervals along $900 \mathrm{~m}$ transects to minimize the probability of counting the same individual on two successive points (Ravokatra et al. 1998, Raherilalao 2006). At each point, all birds seen and heard were recorded within a radius of $25 \mathrm{~m}$ around the point for ten minutes. Transects were placed in parallel and spaced at a $200 \mathrm{~m}$ distance to each other. Ten transects were established at Site 1 and five transects were surveyed at Site 2 and five at Site 3. Inventories were conducted from 0530 to $0830 \mathrm{~h}$ when the activity of diurnal bird is maximal. Each point was surveyed at least five times from January to May 2012. The number of bird species and the number of individuals were averaged per point.

ANTHROPOGENIC IMPACTS. Anthropogenic impacts could either be linked to the activities of zebu (such as trampling, grazing, opening up the forest) or be directly linked to human activities. To measure these impacts, a plot of $10 \mathrm{~m} \times 10 \mathrm{~m}$ was placed around each point count at Sites 2 and 3. As a proxy for disturbance by zebus, we counted the number of zebu feces per $100 \mathrm{~m}^{2}$ and that are not completely dissolved and not very dry. As measures for human disturbance we recorded the amount of woody debris the number of coarse and fine woody debris $>3 \mathrm{~cm}$ in diameter that were on the ground), assuming that people collect dead wood for firewood as they walk along the trail. Information on hunting and the consumption of birds was collected by interviews and direct observations in the villages of Marofijery

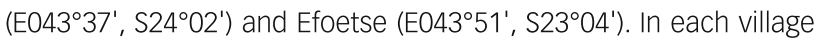
ten people (who have zebu that carried out the transhumance) were interviewed individually.

DATA ANALYSIS. Species similarities between sites were compared based on the presence of species at each site according to the Jaccard index (Magurran 2004). In order to decide on whether or not the Jaccard indices showed a significant difference between sites, we compared the calculated values with values provided by the table for $p=0.05$ provided by Real (1999).

single factor analysis of similarities (ANOSIM) (Clarke 1993, Clarke and Gorley 2001) was used to compare the three study sites using 'PRIMER'. Apart from the presence of species, this comparison also includes the number of individuals per species in the calculation of community similarity. First, we compared the bird communities between different sites (Sites 1, 2, and 3) and second, between the reference site 1 and the combined sites (Sites 2 and 3 ) along the transhumance.

We used the mean number of species and individuals recorded at each point as the unit of analysis. The number of bird species and individuals did not deviate from normality (Kolmogorov-Smirnov-test: $p>0.05$ ). ANOVA was used to compare the number of species and number of individuals between sites. Numbers of bird species and individuals were related to the mea- 


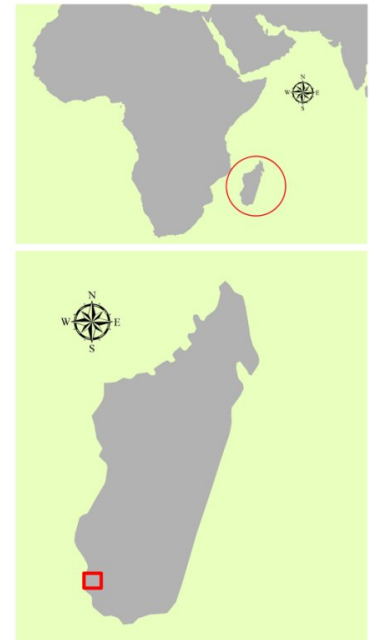

\section{Legend}

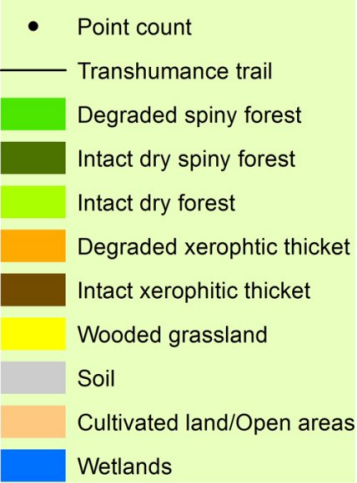

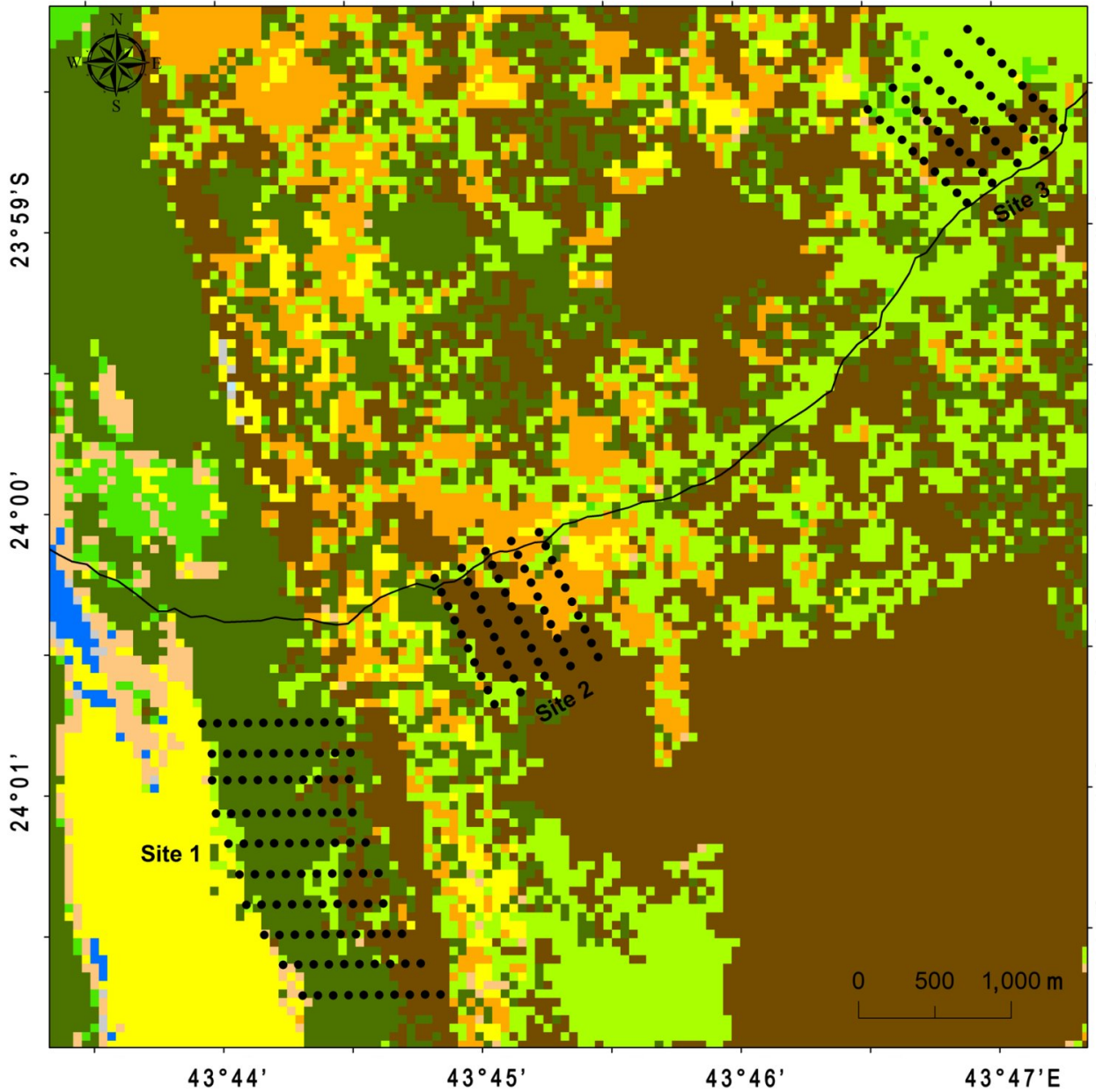

$43^{\circ} 44^{\prime}$

$43^{\circ} 45^{\prime}$

$43^{\circ} 46^{\prime}$

$43^{\circ} 47^{\prime} \mathrm{E}$

Figure 1. Vegetation types and location of the three study sites in the Tsimanampesotse National Park in subarid southwestern Madagascar. The classification of vegetation follows Ratovonamana et al. (2011).

sures of disturbance by zebu ( $=$ number of feces) and humans ( availability of dead wood). The two factors are summarized by the distances to the trail of transhumance using correlations and multiple regression analyses (Waite 2000). SPSS 9.0 (1999) was used to analyze the data. Data on anthropogenic pressure have been log10-transformed to achieve normality.

\section{RESULTS}

At all three sites 6,359 individuals of birds were recorded. These were represented by 55 species: 53 species at Site 1, 41 at Site 2, and 39 at Site 3 (Supplementary Material Table S1).

BIRD SPECIES SIMILARITIES BETWEEN SITES. The mean number of species recorded per point did not differ between Sites 1 and 3, but was significantly lower at Site 2 than at Sites 1 and 3 (ANOVA: overall model: $F=8.80, p<0.001$; Table 2). The mean number of individuals was significantly lower at Site 3 than at either site 1 or site 2 according to Scheffe's post-hoc test

Table 1. Percentage of vegetation types present at the three study sites. Degraded forest is a forest that has undergone disturbance like logging or roaming.

\begin{tabular}{l|l|c|c|c}
\hline Name & Vegetation & Site 1 & Site 2 & Site 3 \\
\hline Spiny forest & Intact spiny forest & $71 \%$ & & \\
\multirow{2}{*}{ Xerophytic thicket } & Intact xerophytic thicket & $18 \%$ & $56 \%$ & $30 \%$ \\
& Degraded xerophytic thicket & & $34 \%$ & \\
\cline { 2 - 5 } Dry forest & Intact dry forest & $11 \%$ & $10 \%$ & $38 \%$ \\
\cline { 2 - 5 } & Degraded dry forest & & & $32 \%$ \\
\hline
\end{tabular}

(ANOVA: overall model: $F=18.36, p<0.001)$. The number of individuals per point did not differ significantly between Sites 1 and 2 according to scheffe's post-hoc test.

Based on the presence and absence of species at each site, the comparison via Jaccard indices showed that sites 2 and 3 $(0.77)$ were the most similar. Sites 1 and $3(0.67)$ differed most (Table 3). None of these values indicate a significant difference of species similarities between sites (Real 1999).

COMMUNITY SIMILARITIES BETWEEN SITES. Taking the abundance of the various species into account, the ANOSIM analysis indicated that the bird communities of the three sites were significantly different with $p<0.001(R=0.76)$. Site 1 also differed from the combined sites along the trail used for the transhumance (Sites 2 and 3; $R=0.82, p<0.001$ ).

ANTHROPOGENIC IMPACTS. The number of bird species and individuals decreased significantly from the edge to the forest interior at the control site (Site 1; Table 3, Figure 2). In contrast, the number of bird species and individuals increased significantly with increasing distance to the trails of transhumance at Site 2. At Site 3 the number of bird species and individuals also increased with increasing distance to the trail; here, the correlation between the distance to the trail and the number of bird species was significant while the distance and number of individuals were also related positively but the correlation was not significant (Figure 2). 
Table 2. Number of bird species and number of individuals per point count at Sites 1-3. (values are means \pm standard deviations. At Site 1 each point is based on data from 10 transects; at Sites 2 and 3 each point is based on data from 5 transects per site. Statistics at the bottom of the table are based on Pearson correlations between the number of species or individuals and the distance)

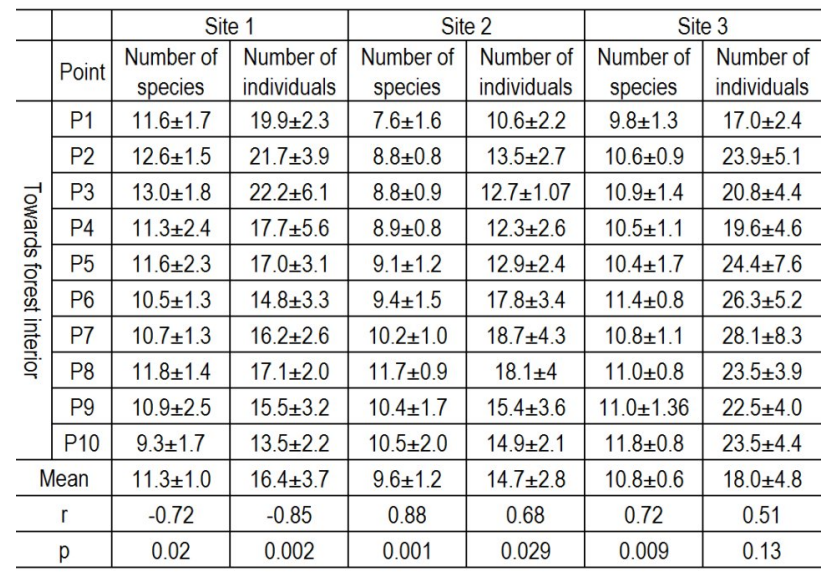

Indicators for anthropogenic pressure (woody debris, number of zebu feces) were measured only at the points of Sites 2 and 3. Therefore the following analyses had to be restricted to sites 2 and 3.The number of bird species and individuals recorded per point was correlated significantly with the abundance of woody debris (Species: $r=0.733, p<0.001$; Individuals: $r=0.699, p<$ $0.001, N=20$ ). The number of bird species was uncorrelated with the number of zebu feces ( $r=0.242, p=0.304)$ but the number of individuals was correlated significantly with the abundance of zebu feces ( $r=0.482, p=0.031)$. Taking site effects into account in analyses of covariance, the abundance of woody debris remained a significant predictor for bird species and individuals while the abundance of zebu feces became insignificant (Table 4).

HUNTING. According to the 20 interviewees from the villages

of Marofijery and Efoetsy, about 30-50 zebus carry out the transhumance with at least two people to attend herds. The transhumance across the national park and takes one day and one night. During this time, about two birds are consumed by two or three people. The number and species of birds consumed during transhumance is represented in Figure 3. Seventy percent of interviewees (men and women who had participated in the transhumance) consumed Coua cursor, followed by Numida meleagris consumed by $50 \%$ of the villagers. Turnix nigricollis is little used because it is taboo for some villagers, even though all villagers come from the south-west but from several different families. In fact, $5 \%$ of the villagers surveyed ate this species. However, bird hunting is not only during transhumance period but during all daily activity of humans. The interviews have also shown that humans hunted birds whenever they are encountered.

Table 3. Pairwise comparisons based on the Jaccard index, and results of the comparison between pairs of sites according to ANOSIM; based on the relative abundance of birds. (values are R-values as calculated by ANOSIM; all comparisons are different with $p<0.05$ )

\begin{tabular}{c|c|c|c|c}
\hline & \multicolumn{2}{|c|}{ Jaccard index } & \multicolumn{2}{c}{ R values (ANOSIM) } \\
\cline { 2 - 5 } & Site 2 & Site 3 & Site 2 & Site 3 \\
\hline Site 1 & 0.70 & 0.67 & 0.80 & 0.83 \\
\hline Site 2 & & 0.77 & & 0.66 \\
\hline
\end{tabular}
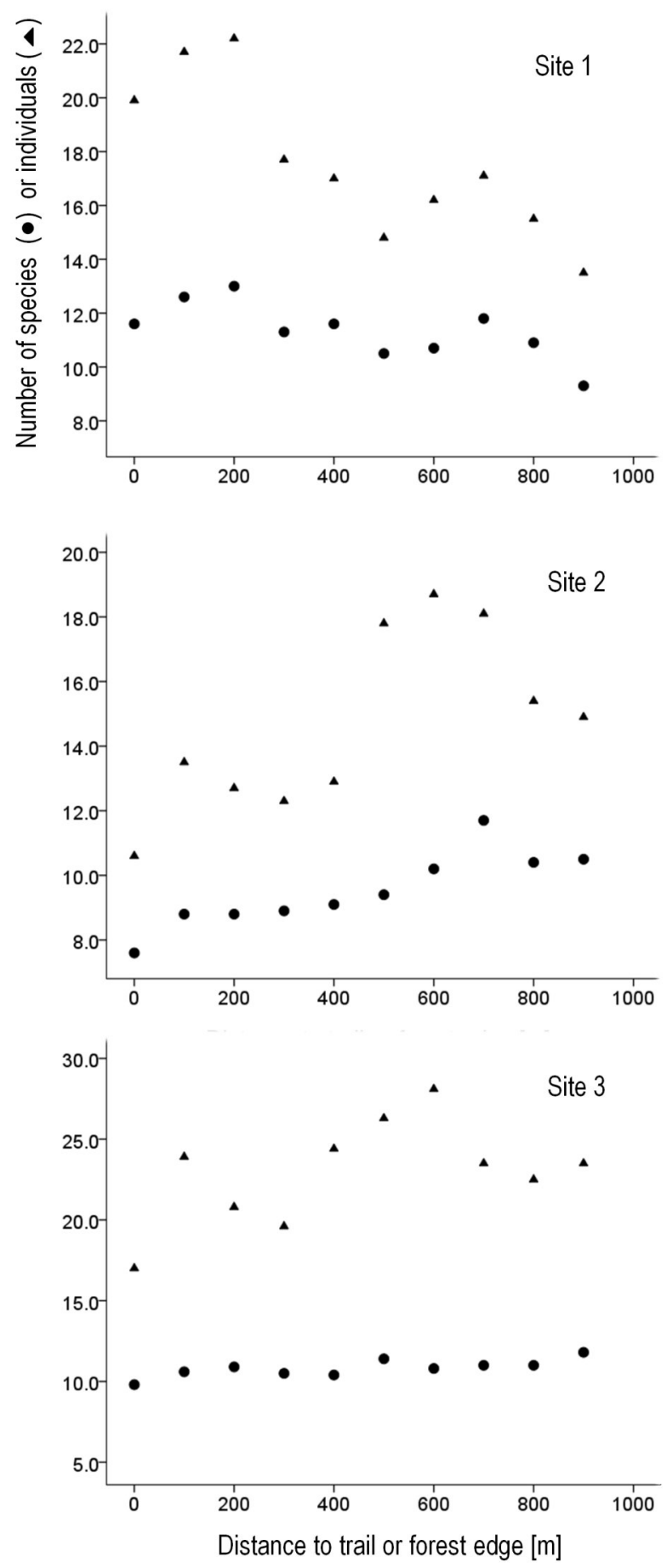

Figure 2. Bird species and individual numbers from the forest edge (Site 1) or the trail of transhumance (Sites 2 and 3 ) towards the forest interior.

\section{DISCUSSION}

In this study we assessed possible effects of the transhumance through Tsimanampesotse National Park on the community composition and density of birds. We used one control site and two sites along the route of transhumance. While densities of different bird species varied between sites, indicating different habitat qualities of the different sites (Collin 1996), the inventories did not reveal any difference in bird species composition between the three sites. The lack of differences in species composition is surprising as the three sites include different vegetation formations, ranging from dry forest to degraded spiny bush (Ratovonamana et al. 2011). The lack of differentiation might be due to our sampling 
Table 4. Impact of human activities (measured by the abundance of dead wood) and zebus (measured by the abundance of zebu feces) after corrections for site specific effects at sites 2 and 3 . (values are F-values according to analyses of covariance)

\begin{tabular}{l|c|c}
\hline & Bird species & Bird individuals \\
\hline Site & 2.25 & $12.07^{* *}$ \\
\hline Dead wood & $9.21^{* *}$ & $5.50^{*}$ \\
\hline Zebu feces & 0.13 & 0.06 \\
\hline
\end{tabular}

that was not designed specifically to assess possible differences between vegetation formations or probabilities of bird detection likely varied between points. Alternatively, it could reflect the need of the various bird species to avoid tight habitat specializations in this region that is characterized by unpredictable rainfall and large fluctuations in ambient conditions (Dewar and Richard 2007, Ratovonamana et al. 2011). Similarly to the situation in birds, neither lemurs nor reptiles show pronounced differences in densities or species composition in relation to habitat degradation at Tsimanampesotse (Rakotondranary et al. 2010, Raonizafinarivo 2013).

In contrast to the general characteristics of the bird communities at the three sites, birds responded differently at the two sites along the transhumance than at a site without pronounced human impacts. At the sites of transhumance, bird species numbers and less consistently also their abundance increased towards the forest interior with increasing distance to the trail, while at the protected site, their numbers decreased from the forest edge to the interior (Figure 2). Such an edge effect is to be expected as edges tend to be more productive and allow species with different specializations to overlap (McCollin 1998).

The reversed situation along the trail of transhumance, which can be considered either as equivalent to a forest edge or simply as a linear structure in an otherwise continuous forest, calls for an explanation. According to our original hypotheses and based on the increase of bird species with increasing distance to the trail, we expected some kind of anthropogenic impact along the trail of transhumance. These impacts could either be linked to the presence of zebu or to the presence of humans. The abundance of zebu feces was not linked to bird species or bird individuals in any systematic manner. Thus, zebus during the transhumance do not seem to have any systematic effects on the birds in the vicinity. In

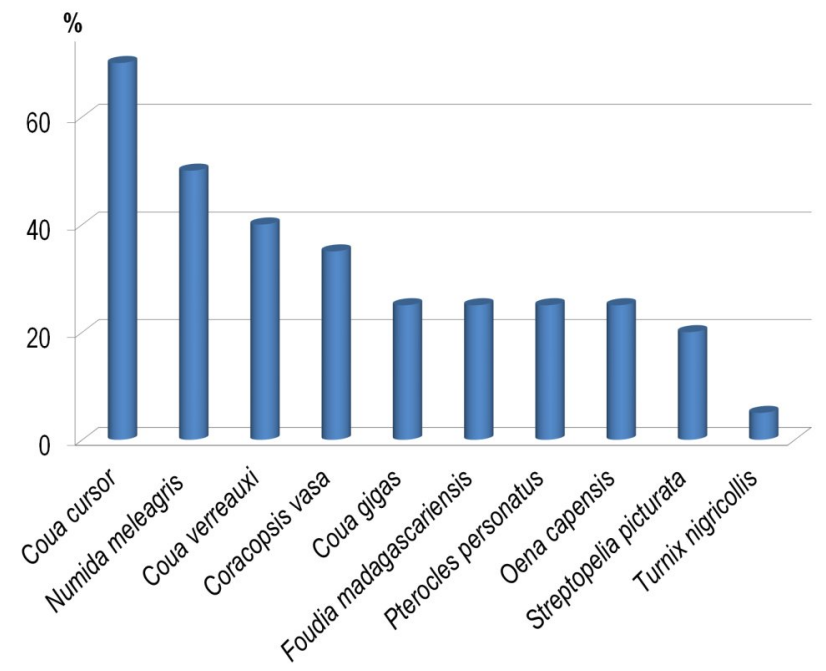

contrast, human presence as indicated by the collection of fire wood (measured as the declining availability of woody debris) seems to have a consistent negative effect on bird species and individual numbers. We cannot provide a causal link between human presence and the reduction of bird abundances. Hunting along the trail may be one component effect on bird species, specifically for birds that are likely to be hunted only in passing, or living around camp sites. The impact of hunting and bushmeat seems to be more important in Madagascar than people had thought. It is a vital part of the rural economy throughout Madagascar (Golden 2009, Sabel et al. 2009, Jenkins et al. 2011) and important also in the Tsimanampesotse area (Walker and Ranfeliarisoa 2012) with profound effects on population densities of Madagascar's native fauna. For the avifauna, large terrestrial birds such as Coua spp. are the most hunted in Madagascar (Goodman and Raherilalao 2013). According to the result of interview in this study, coua spp. are also the most consumed by the human population in our study area.

Transhumance and the zebus themselves are unlikely to represent a threat to the native bird community as the duration of the transhumance is short. But the trail is used to commute between the plateau and the littoral for a variety of purposes. Even small effects such as undergrowth destruction might add up over the year and result in the observed pattern of bird distributions. As a further potential threat, herds continue to graze in the park with important consequences for forest regeneration and probably also the negative consequences imposed by people as observed along the trail of the transhumance.

To sum up, bird species number and densities were lower along the trail of transhumance than elsewhere. Ten species of birds were hunted to meet the daily needs of people travelling along the trails of transhumance. Thus, while the transhumance itself does not seem to affect bird communities, hunting associated with the transhumance as well as with other activities may represent one of the threats to birds in particular for the largest and most terrestrial birds such as Coua spp.

\section{ACKNOWLEDGMENTS}

The study was carried out under the collaboration between Madagascar National Parks, the Departments of Animal Biology, Department of Plant Biology and Ecology (University of Antananarivo) and the Department of Animal Ecology and Conservation (University of Hamburg). We thank Jacques Rakotondranary, Yedidya Ratovonamana, and all of the MNP and WWF staff in Toliara, for their support. Special thanks go to our para-ecologists Mr. Mahita and Mr. Tsiavota for their help in the field and for their communication skills with the local communities. The study was financed by SuLaMa/BMBF.

\section{REFERENCES}

Bibby, C. J., Burgess, N. D. and Hill, D. A. 2000.Bird census techniques. Academic Press, London.

Blanc, C. P. \& Paulian, R. 1996. Originalité biogéographique de la faune du Sud malgache. In: Biogéographie de Madagascar. W. R. Lourenço (ed.), pp 231-244. Éditions ORSTOM, Paris.

Blanc-Pamard, C. P. \& Ramiarantsoa, R. H. 2003. Madagascar: les enjeux environnementaux. In: L’Afrique. Vulnérable et Défis. M. Lesourd (ed.), pp 354-376. Edition du Temps, Nantes, France. 
Brinkmann, K., Noromiarilanto, F., Ratovonamana, R. Y. and Buerkert, A. 2014. Deforestation processes in south-western Madagascar over the past 40 years: what can we learn from settlement characteristics? Agriculture, Ecosystems and Environment 195:231-243. (doi:10.1016/j.agee.2014.06.008)

Clarke, K. R. 1993. Non-parametric multivariate analysis of changes in community structure. Australian Journal of Ecology 18, 1: 117-143. (doi:10.1111/j.14429993.1993.tb00438.x)

Clarke, K. R. and Gorley, R. N. 2001. PRIMER Version 6 User Manual/Tutorial. Primer-E Ltd, Plymouth.

Collin, L. 1996. Notion d'habitat. In: Aménagement des Boisés et Terres Privés pour la Faune. Ministère de l'Environnement et de la Faune du Québec. Québec, Canada. Available at <http://ow.ly/Tg|MR>

Cornet, A. 1972. Essai de Cartographie Bioclimatique à Madagascar. ORSTOM, Antananarivo.

Dewar, R. E. and Richard, A. F. 2007. Evolution in hypervariable environment of Madagascar. Proceedings of the National Academy of Sciences of the United States of America 104: 13723-13727. (doi:10.1073/pnas.0704346104)

Feldt, T., 2015. Interrelatedness of grazing livestock with vegetation parameters and farmers' livelihoods in the Mahafaly region, southwestern Madagascar. Unpubl. Ph.D. thesis, Faculty of Agricultural Sciences, University of Kassel, Witzenhausen.

Ganzhorn, J. U., Lowry, P. P., Schatz, G. E. and Sommer, S. 2001. The biodiversity of Madagascar: one of the world's hottest hotspots on its way out. Oryx 35, 4 346-348. doi:10.1046/j.1365-3008.2001.00201.x

Golden, C. D. 2009. Bushmeat hunting and use in the Makira Forest north-eastern Madagascar: a conservation and livelihoods issue. Oryx 43: 386-392. (doi:10.1017/S0030605309000131)

Goodman, S. M. and Benstead, J. P. 2005. Updated estimates of biotic diversity and endemism for Madagascar. Oryx 39: 73-77. (doi:10.1017/S0030605305000128)

Goodman, S. M. and Raherilalao, M. J. (eds.) 2013. Atlas of selected land vertebrates of Madagascar. Association Vahatra, Antananarivo.

Goodman, S. M., Raherilalao, M. J., Rakotomalala, D., Rakotondravony, D., Raselimanana, A. P. et al. 2002. Inventaire des vertébrés du Parc National de Tsimanampetsotsa (Toliara). Akon'ny Ala 28: 1-36.

Jenkins, R. K. B., Keane, A., Rakotoarivelo, A. R., Rakotomboavonjy, V., Randrianandrianina, F. H.et al. 2011. Analysis of patterns of bushmeat consumption reveals extensive exploitation of protected species in eastern Madagascar. PLOS ONE 6, 12: e27570. (doi:10.1371/journal.pone.0027570)

Joppa, L. N., Visconti, P., Jenkins, C. N. and Pimm, S. L. 2013.Achieving the Convention on Biological Diversity's goals for plant conservation. Science 341: 1100. (doi:10.1126/science.1241706)

Magurran, A. E. 2004. Measuring Biological Diversity. Blackwell Science Ltd, Hong Kong.

McCollin, D. 1998. Forest edges and habitat selection in birds: a functional approach. Ecography 21, 3: 247-260. (doi:10.1111/j.1600-0587.1998.tb00562.x)

MEEMF (Ministère de l'Environnement, de l'Ecologie, de la Mer et des Forêts) 2015. Décret $n^{\circ}$ 2015-736 du 21 Avril 2015. Antananarivo, Madagascar.

Nedelea, A. and Comnescu, L. 2009. Effects of transhumance on the southern slope of the Fagaras Mountains. GeoJournal of Tourism and Geosites 4, 2: 125-132.

O'Dea, N., Watson, J. E. M. and Whittaker, J. 2004. Rapid assessment in conservation research: A critique of avifaunal assessment techniques illustrated by Ecuadorian and Madagascan case study data. Diversity and Distributions 10, 1: 55-63. (doi:10.1111/j.1472-4642.2004.00050.x)

Primack, R. B. \& Ratsirarson, J. 2005. Principe de Base de la Conservation de la Biodiversité. Université d'Antananarivo, École Supérieure des Sciences Agronomique, Ankatso-Ambohitsaina, Antananarivo.

Projet SuLaMa. 2011. Diagnostic Participatif des Ressources Naturelles sur le Plateau Mahafaly, Commune Rurale de Beheloka-Toliara. <http://www.sulama.de/files/rapport_marp_2011_small.pdf> accessed 23 January 2014.

Raherilalao, M. J. 2006. Contribution à la Connaissance de la Biogéographie des Oiseaux Forestiers des Hautes Terres Malgaches, Unpubl. Thèse de Doctorat troisième cycle, Université d'Antananarivo, Antananarivo. http://www.theses.recherches.gov.mg accessed 18 July 2012.
Raherilalao, M. J. \& Goodman, S. M. 2011. Histoire Naturelle des Familles et SousFamilles Endémiques d'Oiseaux de Madagascar. Association Vahatra, Antananarivo.

Raherilalao, M. J. \& Wilmé, L. 2008. L'avifaune des forêts des sèches malgaches. In: Les Forêts Sèches de Madagascar, S. M. Goodman et L. Wilmé (eds.). Malagasy Nature 1: 76-105

Rakotondranary, J. S., Ratovonamana, Y. R. \& Ganzhorn, J. U. 2010. Distributions et caractéristiques des microhabitats de Microcebus griseorufus (Cheirogaleidae) dans le Parc National de Tsimanampetsotsa (Sud-ouest de Madagascar). Malagasy Nature 4: 55-64.

Raonizafinarivo, S. 2013. Effets de l'Agriculture et du Pâturage sur la Communauté d'Oiseaux dans la Région du Parc National de Tsimanampetsotsa. Unpubl. MSc Biologie Animale. Université d'Antananarivo, Antananarivo. <http://www.theses.recherches.gov.mg> accessed 10 September 2015.

Ratovonamana, R. Y., Rajeriarison, C., Roger, E. and Ganzhorn, J. U. 2011. Phenology of different vegetation types in Tsimanampetsotsa National Park, southwestern Madagascar. Malagasy Nature 5: 14-38.

Ratovonamana, Y. R, Rajeriarison, C., Edmond, R., Kiefer, I. and Ganzhorn, J. U. 2013. Impact of livestock grazing on forest structure, plant species composition and biomass in southwestern Madagascar. In: African Plant Diversity, Systematics and Sustainable Development. N. Beau, S. Dessein, E. Robbrecht (eds.), pp 82-92. Proceedings of the XIXth AETFAT Congress, held at Antananarivo, Madagascar, 26-30 April 2010 Scripta Botanica Belgica. National Botanic Garden of Belgium, Meise.

Ravokatra, M., Wilmé, L. \& Goodman, S. M. 1998. Les oiseaux. In: Inventaire Biologique Forêt d'Andranomay, Anjozorobe. D. Rakotondravony \& S. M. Goodman (eds.). Recherches pour le Développement, série Sciences Biologiques 13: $60-73$.

Real, R. 1999. Tables of significant values of Jaccard's index of similarity. Miscellania Zoologica 22, 1: 29-40.

Sabel, J., Green, K., Dawson, J., Robinson, J., Garden, C. et al. 2009. The conservation status of mammals and avifauna in the Montagne des Français massif, Madagascar. Madagascar Conservation \& Development 4, 1: 44-51. (doi:10.4314/mcd.v4i1.44012)

Soarimalala, V. \& Raherilalao, M. J. 2008. Pression et menace dans la région forestière sèche malgache. In: Les Forêts Sèches de Madagascar. S. M. Goodman \& L. Wilmé (eds.). Malagasy Nature 1: 157-161.

SPSS. 1999. SPSS Base 9.0 User's Guide. SPSS Inc. Chicago.

Waite, S. 2000. Statistical Ecology in Practice. A Guide to Analysing Environmental and Ecological Field Data. Pearson Education Limited, Harlow, UK.

Walker, R. C. J. and Rafeliarisoa, T. H. 2012. Distribution of radiated tortoise (Astrochelys radiata) bushmeat poaching effort. Chelonian Conservation and Biology 11, 2: 223-226. (doi:10.2744/CCB-0968.1)

\section{SUPPLEMENTARY MATERIAL.}

AVAILABLE ONLINE ONLY.

Table S1. Occurences of species at the different sites. 